\title{
Zsummary Preservation
}

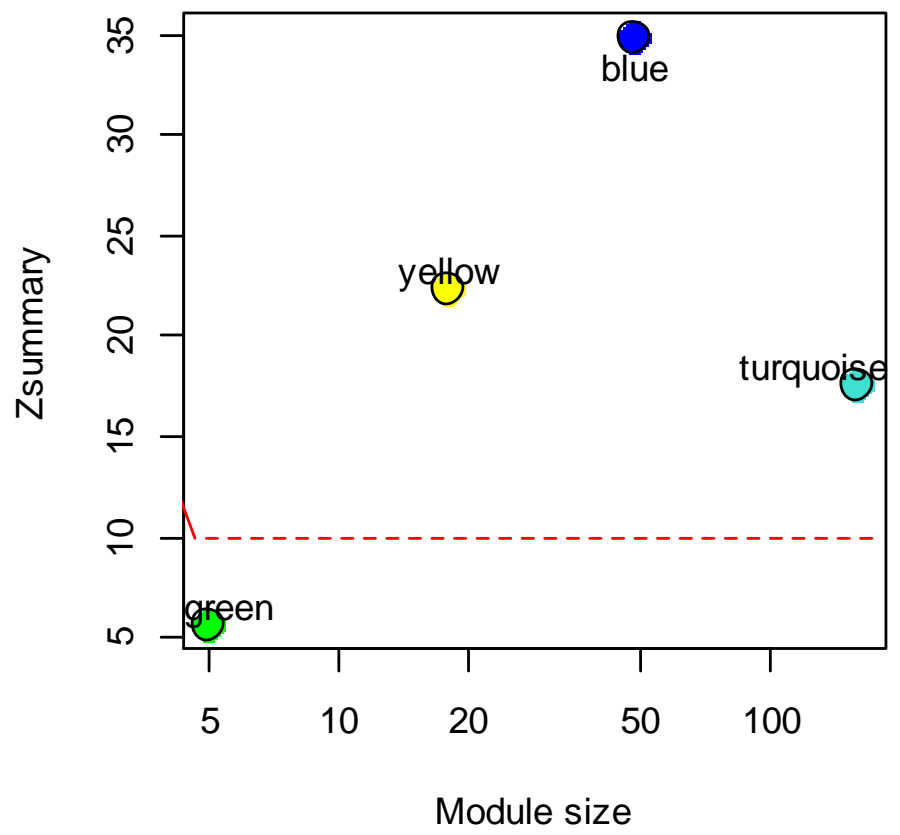

